\title{
KEWASPADAAN PERAWAT DALAM PENULARAN PENYAKIT TUBERKULOSIS (TB) PARU SAAT MELAKSANAKAN TUGAS DI RUMAH SAKIT
}

\author{
Nabila Rahmadhani \\ @rahmadhaninabila2@gmail.com
}

\begin{abstract}
Diseases resulting from the operation of various factors either from the agent, the landlord or the environment. In epidemiology there are three factors that can explain the spread (distribution) of disease or health problems, namely person (person), place (place), and time (time). Tuberculosis (TB or $\mathrm{TB}$ ) is an infectious disease of the respiratory tract caused by bacteria. Tuberculosis (TBC) is an infectious disease that is still of concern to the world, until now there is no single country that is free from TB, including Indonesia. Transmission of tuberculosis is caused by the Mycobacterium tuberculosis germs which are transmitted through the air (droplet nuclei) when a tuberculosis patient coughs and saliva that contains bacteria is inhaled by other people while breathing.
\end{abstract}

Keywords: infectious diseases, pulmonary tuberculosis (TB)

\begin{abstract}
Abstrak
Penyakit menular timbul akibat dari beroperasinya berbagai faktor baik dari agen, induk semang atau lingkungan. Dalam epidemiologi ada tiga faktor yang dapat menerangkan penyebaran (distribusi) penyakit atau masalah kesehatan yaitu orang (person), tempat (place), dan waktu (time). Tuberculosis (TBC atau TB) adalah penyakit infeksi pada saluran pernafasan yang disebabkan oleh bakteri. Tuberculosis (TBC) merupakan penyakit menular yang masih menjadi perhatian dunia, hingga saat ini belum ada satu negara pun yang bebas dari TBC termasuk Indonesia. Penularan penyakit Tuberkulosis disebabkan oleh kuman Mycobacteriun tuberculosis ditularkan melalui udara (droplet nuclei) saat seorang pasien Tuberkulosis batuk dan percikan ludah yang mengandung bakteri terhirup oleh orang lain saat bernapas.
\end{abstract}

Kata kunci : penyakit menular, tuberculosis (TB) paru 


\section{Latar belakang}

pidemiologi Penyakit Menular

Perkembangan ilmu pengetahuan dan teknologi dalam bidang kedokteran mendorong para tenaga ahli selalu mengadakan riset terhadap berbagai penyakit termasuk salah satunya adalah penyakit menular demi mengatasi kejadian penderitaan dan kematian akibat penyakit. Pengertian Epidemiologi menurut asal kata, jika ditinjau dari asal kata Epidemiologi berasal dari bahasa Yunani yang terdiri dari 3 kata dasar yaitu Epi yang berarti pada atau tentang, Demos yang berarti penduduk dan kata terakhir adalah Logos yang berarti ilmu pengetahuan. Jadi Epidemiologi adalah ilmu yang mempelajari tentang penduduk. Sedangkan dalam pengertian modern pada saat ini adalah ilmu yang mempelajari tentang frekuensi dan distribusi (penyebaran) serta determinant masalah kesehatan pada sekelompok orang atau masyarakat serta determinasinya (faktorfaktor yang mempengaruhinya).

Penyakit menular timbul akibat dari beroperasinya berbagai faktor baik dari agen, induk semang atau lingkungan. Bentuk ini tergambar didalam istilah yang dikenal luas dewasa ini. Yaitu penyebab majemuk (multiple causation of disease) sebagai lawan dari penyebab tunggal ( single causation). Didalam usaha para ahli untuk mengumpulkan pengetahuan mengenai timbulnya penyakit, mereka telah melakukan eksperimen terkendali untuk menguji sampai dimana penyakit itu bisa di cegah sehinga dapat meningkat taraf hidup penderita. Dalam epidemiologi ada tiga faktor yang dapat menerangkan penyebaran (distribusi) penyakit atau masalah kesehatan yaitu orang (person), tempat (place), dan waktu (time). Informasi ini dapat digunakan untuk menggambarkan adanya perbedaan keterpaparan dan kerentanan. Perbedaan ini bisa digunakan sebagi petunjuk tentang sumber, agen yang bertanggung jawab, transisi, dan penyebaran suatu penyakit.

Penyakit tidak menular di ketahui sebagai penyakit yang tidak dapat disebarkan dari seseorang terhadap orang lain. Terdapat empat tipe utama penyakit tidak menular yaitu penyakit kardiovaskuler, kanker, penyakit pernapasan kronis, dan diabetes. Pola hidup modern telah mengubah sikap dan perilaku manusia, termasuk pola makan, merokok, konsumsi alkohol serta obatobatan sebagai gaya hidup sehingga penderita penyakit degeneratif (penyakit karena penurunan fungsi organ tubuh) semakin meningkat dan mengancam kehidupan.

Penyakit tidak menular (PTM), dikenal juga sebagai penyakit kronis, tidak ditularkan dari orang ke orang. Perkembangan penyakit tidak menular 
umumnya lambat dan membutuhkan durasi yang panjang. Berdasarkan profil WHO mengenai penyakit tidak menular di Asia Tenggara, ada lima penyakit tidak menular dengan angka kesakitan dan kematian yang tinggi, yaitu penyakit kardiovaskuler, kanker, penyakit pernapasan kronis, dibetes mellitus, dan cedera. Empat terbanyak dari penyakit tidak menular yaitu penyakit kardiovaskuler, kanker, penyakit pernapasan kronis dan diabetes militus.

Penyakit tidak menular telah menjadi kelompok didefinisikan. penyakit yang sulit untuk Istilah penyakit tidak menular menjadi sebuah ironi karena beberapa penyakit yang termasuk seperti kanker leher rahim, perut, dan hati sebagian disebabkan infeksi organisme. Namun, empat tembakau, konsumsi alkohol, pola makan yang buruk, dan kurangnya aktivitas fisik merupakan oleh perilaku seperti penggunaan perilaku yang menjadi faktor risikodan berhubungan erat dengan empat penyakit tidak menular utama (penyakit kardiovaskuler, kanker, penyakit pernapasan kronis, diabetes) yang mencapai $80 \%$ menyebabkan dari kelompok penyakit tidak kematian menular.

Tuberkulosis merupakan salah satu penyakit yang angka kasusnya cukup tinggi di Indonesia. Dan bila dibandingkan dengan negara lain, Indonesia termasuk negara yang memiliki banyak penderita tuberkulosis. ebanyakan kasus ini terjadi pada negara-negara yang berkembang serta negara yang memiliki kepadatan penduduk yang tinggi.

\section{Metode}

Metode yang penulis gunakan dalam kajian ini adalah metode literature review, di mana pada saata melakukan penulisan kajian ini dibuat berdasarkan dari berbagai suber bacaan yang ada dan berupa, buku bacaan, jurnal, tesis juga maupun ebook yang berhubunga dengan keselamatan dan kesehatan Kerja, upaya yaitu mengenai kepwaspadaan perawat atas penyakit yang dapat menular dari pasien ke perawat atau pun sebaliknya dari perawat ke pasien serta menjelaskan tentang penyekit menular yaitu tuberculosis (TB) paru yang sangat berhubungan dengan $\mathrm{k} 3 \mathrm{rs}$.

Kajian ini juga merupakan kajian bebas dimana adalah kajian ini bersifat bebas dimana kajian ini juga di buat dengan cara melakukan perbandingan dengan artikel satu dan artikel-artikel yang berhubungan dengan kajian yang di lakukan dan hasil dari perbandingan tersebut di tulis secara berurutan dan bertauran dalam hasil kajian ini agar dapat di pahami dengan baik dan menghasilkan kajian yang dapat di terima dengan baik. Sehingga penulisan kajian ini dapat bermanfaat untuk banyak kalangan. 


\section{Hasil}

Hasil dari metode ini adalah Pelaksanaan Keselamatan dan Kesehatan Kerja (K3) adalah salah satu bentuk upaya untuk menciptakan tempat kerja yang aman, sehat, bebas dari pencemaran lingkungan, sehingga dapat mengurangi dan bebas dari kecelakaan kerja danp enyakit akibat kerja yang pada akhirnya dapat meningkatkan efisiensi dan produktivitas kerja.

Namun dalam penerapan

Keselamatan dan Kesehatan Kerja (K3) masih juga banyak didapati perawat perawat yang terkena penyakit akibat kerja yang di lakukan di klinik, rumah sakit atau instansi kesehatan lainnya. Oleh sebab itu Keselamatan dan Kesehatan Kerja di rumah sakit harus lebih memperhatikan dari program tersebut agar kejadia perawat yang terkena penyakit di saat melakukan tugas sebagai seorang perawat dapat di minimalisir ke beradaannya atau sampai tercapainya zero accident.

Dalam melakukan tugasnya perawat bisa saja terinfeksi penyakit menular yaitu Penyakit yang timbul akibat dari beroperasinya berbagai faktor baik dari agen, induk semang atau lingkungan. Sehingga perawat dan tenaga kesehatan lainnya harus lebih waspada terhadap penularan penyakit yang ada di rumah sakit. Penyakit menular ini dapat di tularkan dari pasien ke perawat atau dari perawat ke pasien.

Tuberkulosis (TB) paru ini adalah salah satu penyakit menular yang dapat di tularan dari pasien ke perawat. Penularan penyakit Tuberkulosis disebabkan oleh kuman Mycobacteriun tuberculosis ditularkan melalui udara saat seorang pasien Tuberkulosis batuk dan percikan ludah yang mengandung bakteri terhirup oleh perawat yang sedang bertugas.

Untuk menghindari penularan penyakit ini perawat harus melakukan pencegahan-pencegahan seperti selalu memperhatikan hygiene perorangan, serta proteksi terhadap bahaya dan kecelakaan kerja dengan menggunakan alat pelindung diri (APD) seperti kacamata kerja, masker, sarung tangan, memperhatikan kesterilan alat yangdi gunakan dan lain sebagainya. Serta perawat harus meningkatkan pengetahuan mengenai penyakit-penyakit yang dapat menular ke dirinya sehingga perawat dapat lebih waspada dalam melakukan tindakan keperawatan yang akan di lakukan.

\section{Pembahasan}

Dalam rangka memahami model epidemiologi, pertama kita perlu memahami terminologi penyakit menular, biasanya dan paling sederhana dikategorikan sebagai akut atau kronis. Istilah akut mengacu pada "cepat" atau kata lain disebut juga "infeksi", di mana 
respon imun relatif cepat menghilangkan patogen setelah periode waktu yang singkat ( hari atau minggu ). Sebagai contoh infeksi akut termasuk influenza, distemper, rabies, cacar air, dan rubella. Sedangkan infeksi kronis, berlangsung selama jangka waktu yang lebih lama ( bulan atau tahun ) dan contoh termasuk herpes dan chlamydia.

Model dengan berfokus pada infeksi akut, dengan asumsi patogen penyebab penyakit untuk jangka waktu yang diikuti oleh ( biasanya seumur hidup ) imunitas . Skenario ini secara matematis digambarkan oleh apa yang disebut model SIR ( Dietz 1967 ), model dasar didalam pemodelan epidemiologi penyakit menular. Fomula ini, yang awalnya dipelajari secara mendalam oleh Kermack dan McKendrick ( 1927$)$, mengkategorikan penjamu (host) dalam suatu populasi sebagai kelompok rentan (Susceptible) (jika sebelumnya tidak terpajan patogen penyakit ), terinfeksi (Infected) (jika saat ini terinfeksi oleh patogen ), dan pulih (Recovered) ( jika mereka telah bersih dari infeksi ).

Tuberkulosis (TB) adalah suatu penyakit granulomatosa kronis menular yang disebabkan oleh MT. Penyakit ini biasanya mengenai paru, tetapi dapat menyerang semua organ atau jaringan tubuh, misalnya pada lymph node, pleura dan area osteoartikular. Biasanya pada bagian tengah granuloma tuberkel mengalami nekrosis perkijuan (Depkes RI, 2002). Tuberculosis (TB) adalah penyakit menular langsung yang disebabkan oleh oleh kuman TB (Mycobacterium tuberculosis). Sebagian besar kuman TB menyerang paru, tetapi dapat juga mengenai organ tubuh lainnya (Depkes RI, 2007).

Penularan penyakit Tuberkulosis disebabkan oleh kuman Mycobacteriun tuberculosis ditularkan melalui udara (droplet nuclei) saat seorang pasien Tuberkulosis batuk dan percikan ludah yang mengandung bakteri terhirup oleh orang lain saat bernapas. Sumber penularan adalah pasien Tuberkulosis paru BTA positif, bila penderita batuk, bersin atau berbicara saat berhadapan dengan orang lain, basil Tuberkulosis tersembur dan terhisap ke dalam paru orang sehat dan bisa menyebar ke bagian tubuh lain melalui peredaran darah pembuluh limfe atau langsung ke organ terdekat. Sekali batuk dapat menghasilkan sekitar 3000 percikan dahak. Masa inkubasinya selama 3-6 bulan (Widoyono, 2005).

Upaya pencegahan adalah upaya kesehatan yang dimaksudkan agar setiap orang terhindar dari terjangkitnya suatu penyakit dan dapat mencegah terjadinya penyebaran penyakit. Tujuannya adalah untuk mengendalikan faktor-faktor yang mempengaruhi timbulnya penyakit yaitu 
penyebab penyakit (agent), manusia atau tuan rumah (host) dan faktor lingkungan (environment) (Notoatmodjo, 2007). Dalam epidemiologi, pencegahan dibagi menjadi 3 tingkatan sesuai dengan perjalanan penyakit meliputi, pencegahan primer, pencegahan sekunder dan pencegahan tersier. Pencegahan tingkat pertama atau pencegahan primer merupakan upaya untuk mempertahankan orang yang sehat agar tetap sehat atau mencegah orang yang sehat menjadi sakit. Upaya pencegahan primer yaitu pencegahan umum (mengadakan pencegahan pada masyarakat umum contohnya pendidikan kesehatan masyarakat dan kebersihan lingkungan) dan pencegahan khusus (ditujukan pada orang-orang yang mempunyai resiko terkena penyakit). Pencegahan tingkat kedua atau pencegahan sekunder merupakan upaya manusia untuk mencegah orang yang telah sakit agar sembuh, menghambat progresifitas penyakit, menghindarkan komplikasi dan mengurangi ketidakmampuan. Pencegahan sekunder ini dapat dilakukan dengan cara mendeteksi penyakit secara dini dan mengadakan pengobatan yang cepat dan tepat. Pencegahan tingkat ketiga atau pencegahan tersier dimaksudkan untuk mengurangi ketidakmampuan dan mengadakan rehabilitasi. Upaya pencegahan tersier ini dapat dilakukan dengan cara memaksimalkan fungsi organ yang cacat, membuat protesa ekstremitas akibat amputasi dan mendirikan pusatpusat rehabilitasi medik (Budiarto, 2002).

\section{Klasifikasi Tb Paru}

TB paru BTA (+) adalah:

a. Sekurang-kurangnya 2 dari 3 spesimen dahak menunjukkan hasil BTA positif

b. Hasil pemeriksaan satu specimen sputum menunjukkan BTA positif dan di jumpai adanya kelainan radiologi

c. Hasil pemeriksaan satu specimen sputum menunjukan BTA positif dan biakan positif.

TB paru BTA (-) adalah:

a. Hasil pemeriksaan sputum 3 kali menunjukkan BTA negatif, gambaran klinis dan kelainan radiologi menunjukkan gambaran tuberculosis aktif

b. Hasil pemeriksaan sputum 3 kali menunjukkan BTA negatif dan biakan micobacterium tuberculosis positif.

\section{Gejala Penyakit Tuberkulosis}

Ada beberapa gejala yang umum diderita oleh penderita tuberkulosis, di antaranya:

1. Batuk. Batuk biasanya kronis dan berdahak. Pada anak, dahak sulit dikeluarkan. Pada sebagian orang dapat terjadi batuk berdarah. 
2. Penurunan berat badan. Gejala ini hampir sering ditemui pada penderita tuberkulosis. Anak dengan tuberkulosis terkadang hanya mengalami penurunan berat badan tanpa adanya batuk.

3. Keringat malam

4. Demam. Biasanya ringan dan sering tidak diketahui sebabnya.

5. Lemah dan lesu Tuberkulosis tidak hanya menyerang paru-paru melainkan organ lain juga, termasuk di antaranya tulang, otak, saluran pencernaan, dan sebagainya sehingga gejala yang ditimbulkan cukup beragam tergantung organ yang terinfeksi.

Pengobatan TB paru terbagi atas 2 fase yaitu fase intensif (2-3 bulan) dan fase lanjutan 4 atau 7 bulan. Paduan obat yang digunakan adalah paduan obat utama dan obat tambahan. Jenis obat utama (lini I) adalah INH, rifamfisin, pirazinamid, streptomisisin, etambutol, sedangkan obat tambahan laninnya adalah: kanamisin, amikasin, kuinolon. ada hubungan antara kepatuhan minum obat dengan kesembuhan TBC paru. Dalam penelitian tersebut menyatakan bahwa saat ini semua penderita secara teoritis dapat disembuhkan, asalkan rajin minum obat samapai fase pengobatan selesai dijalankan. Pada umunya kegagalan pengobatan disebabkan oleh karena pengobatan yang terlalu singkat, pengobatan yang tidak teratur dan obat kombinasi yang jelek( Crofton, 2002).

\section{Pencegahan}

Berikut ini adalah penerapan konsep lima tingkatan pencegahan penyakit (five level of prevention disease) pada penyakit akibat kerja, yakni:

a. Peningkatan kesehatan (health promotion). Misalnya: penyuluhan kesehatan dan keselamatan kerja (K3) pendidikan kesehatan, meningkatkan gizi yang baik, pengembangan kepribadian, perusahaan yang sehat dan memadai, rekreasi, lingkungan kerja yang memadai, penyuluhan perkawinan dan pendidikan seksual, konsultasi tentang keturunan dan pemeriksaan kesehatan periodik.

b. Perlindungan khusus (specific protection). Misalnya: imunisasi, hygiene perorangan, sanitasi lingkungan, serta proteksi terhadap bahaya dan kecelakaan kerja dengan menggunakan alat pelindung diri (APD) seperti helm, kacamata kerja, masker, penutup telinga (ear muff dan ear plug) baju tahan panas, sarung tangan, dan sebagainya.

c. Diagnosis (deteksi) dini dan pengobatan segera serta 
pembatasan titik-titik lemah untuk mencegah terjadinya komplikasi.

d. Membatasi kemungkinan cacat (disability limitation). Misalnya: memeriksa dan mengobati tenaga kerja secara komprehensif, mengobati tenaga kerja secara sempurna dan pendidikan kesehatan.

e. Pemulihan kesehatan rehabilitation ). Misalnya: rehabilitasi dan mempekerjakan kemali para pekerja yang menderita cacat. Sedapat mungkin perusahaan mencoba menempatkan keryawan-karyawan cacat di jabatan yang sesuai.

\section{Kesimpulan}

Tuberkulosis (TB) paru ini adalah salah satu penyakit yang dapat di tularkan ke pada perawat yaitu penularan dengan batuk dan percikan ludah yang mengandung bakteri terhirup oleh perawat. Tidak semua orang yang memiliki kontak erat dengan penderita tuberkulosis akan mengidap tuberkulosis paru,bila seseorang yang memiliki imunitas yang kompeten tidak akan mengalami gejala tuberkulosis. Perawat harus meningkatkan pengetahuan tentang penyakit menular yang dapat di tularkan kepadanya serta cara apa saja yang harus di lakukan untuk menghindari terjadinya penularan penyakit di rumah sakit seperti dengan selalu memperhatikan hygiene perorangan, serta proteksi terhadap bahaya dan kecelakaan kerja dengan menggunakan alat pelindung diri (APD) seperti kacamata kerja, masker, sarung tangan, memperhatikan kesterilan alat yangdi gunakan dan lain sebagainya.

\section{Daftar pustaka}

Budiarto, Eko dan Dewi Anggraeni. 2002. Pengantar Epidemiologi Edisi 2. Jakarta: Penerbit Buku Kedokteran EGC

Darlina.Devi. (2011). Manajemen Pasien Tuberculosis Paru. Idea Nursing Journal, 2(1), 27-31.

Djafri. Defriman. (2016). Pemodelan Epidemiologi Penyakit Menular. Jurnal Kesehatan Masyarakat Andalas, 10(1), 1-2

Efendi, F. dan Makhfudli. Keperawatan Kesehatan Komunitas Teori dan Praktik dalam Keperawatan.

Jakarta: Penerbit Salemba Medika; 2009.

Irwan. (2017). Epidemologi Penyakit Menular. Yogyakarta: Penerbit CV.Absolute Media

Muniroh. Nuha. Siti Aisah dan Mifbakhuddin. (2013). FaktorFaktor yang Berhubungan Dengan Kesinambungan Penyakit Tubervulosis (TBC) Paru Di Wilayah Kerja Puskesmas Mangkang Semarang Barat. Jurnal Keperawatan Komunitas . (1)1,3342 
Salawati. Liza. (2015). Penyakit Akibat Kerja dan Pencegahan. Jurnal Kedokteran Syah Kuala, 15 (2), 91-95

Sembiring. Samuel. (2019). Indonesia Bebas Tuberkulosis. Jawa Barat : CV Jejak, anggota IKAPI

Septiani. Putri. (2015). Survei Beberapa Faktor Risiko Penyakit Menular Kabupaten Rembang (Studi pada Sukarelawan). Jurnal Kesehatan Masyarakat (e-Jurnal), 3(1), 182-190.

Simamora, R. H. (2017). A strengthening of role of health cadres in BTAPositive Tuberculosis (TB) case invention through education with module development and video approaches in Medan Padang bulan Comunity Health Center, North Sumatera Indonesia. International Journal of Applied Engineering Research, 12(20), 10026-10035.

Simamora, R. H., \& Saragih, E. (2019). Penyuluhan kesehatan terhadap masyarakat: Perawatan penderita asam urat dengan media audiovisual. JPPM (Jurnal Pendidikan dan Pemberdayaan Masyarakat), 6(1), 24-31.

Warganegara. Efrida. Nida Nabilah Nur.(2016). Faktor Risiko Perilaku Penyakit Tidak Menular. Jurnal Majority, 5(2), 88-94. 